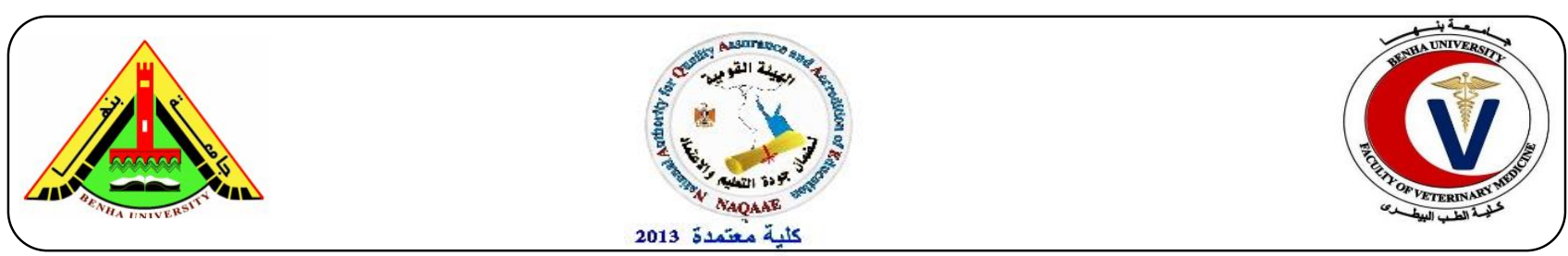

\title{
Prevalence of Staphylococci in Meat Products with Special Reference to Methicillin-Resistant Staphylococcus Aureus (MRSA) at Kaliobia Governorate
}

\author{
${ }^{1}$ Edris A.M. , ${ }^{2}$ Maarouf A.A.A., ${ }^{1}$ Amin R.A.E. and ${ }^{3}$ Bahbah E.A.I. \\ ${ }^{1}$ Food Control Department (Meat Hygiene), Fac. Vet. Med. Benha Univ. \\ ${ }^{2}$ Animal Health Research "Benha branch". \\ ${ }^{3}$ Vet. at GlaxoSmithKline.
}

\section{A B S T R A C T}

The study was carried out on 120 random samples of meat products viz: Minced meat; beef kofta; sausage and beef burger (30 for each) collected from different supermarkets at Kaliobia Governorate to determine their contamination with certain bacteria, specially S. aureus and MRSA. The bacteriological examination of examined meat samples revealed that, the mean value of $S$. aureus counts in minced meat beef kofta, sausage and beef burger samples were $1.58 \times 10^{2} \pm 0.10$ $\times 10^{2} ; 1.41 \times 10^{2} \pm 0.09 \times 10^{2} ; 10.95 \times 10^{2} \pm 0.16 \times 10^{2}$ and $0.83 \times 10^{2} \pm 0.22 \times 10^{2}$, respectively. A total of $70(58.3 \%)$ isolates of Staphylococcus species were recovered, includes 24 S. aureus (20.0\%). The isolated $S$. aureus were highly resistant for methicillin and oxacillin. Meanwhile, they were highly sensitive to norfloxacin. Moreover, the PCR results cleared that, the mecA gene was amplified in 6 out of 8 studied $S$. aureus strains.

Key words: Meat products, Bacteriological evaluation, S. Aureus, MRSA

(http://www.bvmj.bu.edu.eg)

(BVMJ-35(2): 364-374, 2018)

\section{INTRODUCTION}

Meat products are the most palatable highly nutritious foods for human being, as they are important sources for protein, fat, essential amino acids, minerals, vitamins and other nutrients (Zafar et al., 2016). Poor hygienic practices in food processing plants may result in the contamination of meat products with pathogens leading to their spoilage, economic losses, foodborne infections in human and health risk (Yang et al., 2011).

Staphylococcus aureus is the most pathogenic species and it is considered the third-most important cause of food-borne disease in the world (Normanno et al., 2007).
It has two aggravating characteristics, toxin production and antimicrobial resistance and the isolates from meat and its products showed proteolytic and lipolytic activity at+20 ${ }^{\circ} \mathrm{C}$, causing meat spoilage (Gundogan and Devren, 2010). This pathogen is considered an excellent indicator of thermal processing inefficiency, inadequate hygienic conditions during food production / preparation or inadequate cooling after food preparation (Sasidharan et al., 2011). Methicillin-resistant $S$. aureus (MRSA) is known to be one of the most prevalent nosocomial pathogens throughout the world causing a wide range of food poisoning, 
pneumonia, post-operative wound infections and nosocomial infections (Khosravi et al., 2017). In recent years, MRSA has been identified in domestic animals and animalderived food products worldwide (Hanson et al., 2011).

Of the various surveyed food products, meat and its products are widely known to be an important reservoir and main source of MRSA in humans (Jackson et al., 2013 and Contreras et al., 2015). Staphylococci produce disease when the bacteria contaminate food, they produce some enzymes which are implicated with Staphylococcus invasiveness and extracellular substances some of them are heat stable enterotoxins that renders the food dangerous even though it appears normal and extensive cooking can kill the bacteria but the toxins may not be destroyed because most of them are gene based i.e. they can be carried on the plasmid (Prescott et al., 2005). The enterotoxins that can cause food poisoning are produced by about one-third of coagulase positive $S$. aureus strains and growth of enterotoxigenic strains of $S$. aureus to population of at least $10^{5} \mathrm{cfu} / \mathrm{g}$ of food is generally considered necessary for production of sufficient amount of enterotoxins to induce food intoxication (Park et al., 1994). The Staphylococcal enterotoxins (SEs) are responsible for the symptoms that associated with Staphylococcal food poisoning (Llewelyn and Cohen, 2002). The disease is characterized by symptoms including nausea, vomiting, abdominal cramps and diarrhea lasting from 1 to 2 days and usually the complete recovery occurs within 1-3 days (Shijia et al,. 2016). As the level of contamination of beef and its products with Staphylococci constitute serious problems for consumers. Therefore, the study was performed for determination the prevalence of Staphylococci with special reference to $S$. aureus and MRSA beside evaluation the safety of common meat products (minced meat; beef kofta; sausage and beef burger) sold in supermarkets at Kaliobia Governorate.

\section{MATERIALS AND METHODS}

\subsection{Samples collection}

A total of 120 random samples of minced meat; beef kofta; sausage and beef burger ( 30 for each), were purchased from different supermarkets at Kaliobia Governorate, for bacteriological examination to evaluate the bacterial quality and the hygienic health hazard of them with Staphylococci.

\subsection{Bacteriological examination}

1. Preparation of samples (APHA, 2001)

2. Determination of Aerobic Plate Count $(A P C) / g$, using the standard plate count following (FDA, 2001).

3. Determination of Staphylococcus and $S$. aureus counts (FDA, 2001)

4. Isolation and identification of suspected $S$. aureus:

Isolation of $S$. aureus using Baird-Parker agar plates. Suspected colonies were picked up onto slants of nutrient agar for further purification then identified morphologically by Gram-stain; biochemically and coagulase activities according to Quinn et al. (2002).

5. In-Vitro anti-microbial sensitivity test:

The isolated $S$. aureus strains were subjected to the sensitivity test against different antibiotics, using the disc and agar diffusion method (Koneman et al., 1997).

6. Molecular detection of methicillin-resistant $S$. aureus (MRSA):

Methicillin resistant gene (mecA) detection using polymerase chain reaction (PCR) in 8 random isolated $S$. aureus (two isolates from each sample), that showed antibiotic resistant by disk diffusion method to the same studied strains, following QIAamp® DNA Mini Kit instructions (Catalogue no. 51304), Emerald Amp GT PCR mastermix (Takara) with Code No. RR310A, 1.5\% 
agarose gel electrophoreses (Sambrook et al., 1989) using the Primers sequence, target genes amplicons sizes and cycling conditions showed in Table (1).

\section{RESULTS}

The results of bacteriological examination of meat products (minced meat; beef kofta; sausage and beef burger) are presented in Tables (2-6) and Figures (1-2).

The data shown in (Table, 2. 3. 4.) revealed that, The bacteriological examination of examined meat products (minced meat; beef kofta; sausage and beef burger) samples revealed that, the mean value of APC, Staphylococcus and $S$. aureus counts in minced meat samples were $8.02 \times 10^{4} \pm 0.19$ $\times 10^{4} ; 2.92 \times 10^{2} \pm 0.18 \times 10^{2}$ and $1.58 \times 10^{2} \pm 0.10$ $\times 10^{2}$,respectively; for beef kofta samples were $7.59 \times 10^{4} \pm 0.18 \times 10^{4} ; 2.95 \times 10^{2} \pm 0.18 \times 10^{2}$ and $1.41 \times 10^{2} \pm 0.09 \times 10^{2}$, respectively; for

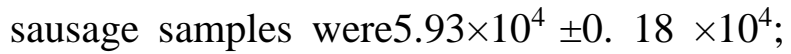
$1.98 \times 10^{2} \pm 0.11 \times 10^{2}$ and $0.95 \times 10^{2} \pm 0.16 \times 10^{2}$, respectively and for beef burger samples were $4.92 \times 10^{4} \pm 0.19 \times 10^{4} ; 1.87 \times 10^{2} \pm 0.12 \times 10^{2}$ and $0.83 \times 10^{2} \pm 0.22 \times 10^{2}$, respectively.

The obtained results in Table (5) revealed that, a total of $70(58.3 \%)$ isolates of Staphylococcus species were recovered from
Data obtained were analyzed according to Snedecor and Cochran (1969) using the computer software program (SPSS, 2001).

120 samples, includes 24 S. aureus (20.0\%); $43 S$. epidermidis $(35.8 \%)$ and $3 S$. chromogenes $(2.5 \%)$. S. aureus were isolated from 24 samples; represented as $8(26.7 \%)$ from minced meat followed by 7 (23.3\%) from beef kofta; 6 (20.0\%) from sausage and $3(10.0 \%)$ from beef burger.

The results of Coagulase activities of isolated Staphylococcus species strains

Table, 6 cleared that, out of 70 isolated Staphylococcus species strains, 24 strains were coagulase positive and all of them were $S$. aureus strains.

The isolated $S$. aureus were highly resistant for methicillin and oxacillin followed by nalidixic acid; cefotaxime; ampicillin and amoxicillin. Meanwhile, they were highly sensitive to norfloxacin followed by lomefloxacin; gentamycin and ciprofloxacin.(Fig.1). Moreover, the PCR results cleared that, the mecA gene was amplified in 6 out of 8 studied $S$. aureus strains (Fig. 2).

Table (1): Primer sequence and target gene.

\begin{tabular}{cccc}
\hline Target gene & $\begin{array}{c}\text { Primer sequence } \\
\left(5^{\prime}-3^{\prime}\right)\end{array}$ & $\begin{array}{c}\text { Amplified } \\
\text { segment }\end{array}$ & Reference \\
& & & \\
\hline mecA & GTA GAA ATG ACT GAA & $310 \mathrm{bp}$. & $\begin{array}{c}\text { McClure } \text { et al., } \\
\text { CGT CCG ATA A }\end{array}$ \\
& CCA ATT CCA CAT TGT & \\
TTC GGT CTA A & \\
\end{tabular}


Table (2): Aerobic plate counts /g. (APC) in the examined samples of meat products $(\mathrm{n}=30$ for each sample)

\begin{tabular}{cccc}
\hline Samples & Min. & Max. & Mean $\pm \mathrm{SEM}^{* *}$ \\
& & & \\
\hline Beef Burger & $2.5 \times 10^{4}$ & $6.6 \times 10^{4}$ & $4.92 \times 10^{4} \pm 0.19 \times 10^{4 \mathrm{c}}$ \\
Beef Kofta & $4.4 \times 10^{4}$ & $9.1 \times 10^{4}$ & $7.59 \times 10^{4} \pm 0.18 \times 10^{4 \mathrm{a}}$ \\
Minced Meat & $4.9 \times 10^{4}$ & $9.8 \times 10^{4}$ & $8.02 \times 10^{4} \pm 0.19 \times 10^{4 \mathrm{a}}$ \\
Sausage & $3.8 \times 10^{4}$ & $7.9 \times 10^{4}$ & $5.93 \times 10^{4} \pm 0.18 \times 10^{4 \mathrm{~b}}$ \\
\hline
\end{tabular}

* Percentage in relation to total number of samples in each row.

Table (3): Staphylococci counts/g. in the examined samples of meat products $(n=30)$

\begin{tabular}{cccccc}
\hline Samples & \multicolumn{2}{c}{ Positive } & Min. & Max. & Mean \pm SEM \\
\cline { 2 - 3 } & No. & $\%^{*}$ & & & \\
\hline Beef Burger & 14 & 46.7 & $1.2 \times 10^{2}$ & $2.5 \times 10^{2}$ & $1.87 \times 10^{2} \pm 0.12 \times 10^{2 \mathrm{~b}}$ \\
Beef Kofta & 19 & 63.3 & $2.2 \times 10^{2}$ & $4.6 \times 10^{2}$ & $2.95 \times 10^{2} \pm 0.18 \times 10^{2 \mathrm{a}}$ \\
Minced Meat & 20 & 66.7 & $1.6 \times 10^{2}$ & $4.8 \times 10^{2}$ & $2.92 \times 10^{2} \pm 0.18 \times 10^{2 \mathrm{a}}$ \\
Sausage & 17 & 56.7 & $1.2 \times 10^{2}$ & $2.9 \times 10^{2}$ & $1.98 \times 10^{2} \pm 0.11 \times 10^{2 \mathrm{~b}}$ \\
\hline
\end{tabular}

* Percentage in relation to total number of samples in each row (30).

Table (4): S. aureus counts/g. in the examined samples of meat products $(n=30)$.

\begin{tabular}{cccccc}
\hline \multirow{2}{*}{ Samples } & \multicolumn{2}{c}{ Positive } & Min. & Max. & Mean \pm SEM \\
\cline { 2 - 4 } & No. & $\%^{*}$ & & & \\
\hline Beef Burger & 3 & 10.0 & $0.4 \times 10^{2}$ & $1.1 \times 10^{2}$ & $0.83 \times 10^{2} \pm 0.22 \times 10^{2 \mathrm{~b}}$ \\
Beef Kofta & 7 & 23.3 & $1.1 \times 10^{2}$ & $1.7 \times 10^{2}$ & $1.41 \times 10^{2} \pm 0.09 \times 10^{2 \mathrm{a}}$ \\
Minced & 8 & 26.7 & $1.2 \times 10^{2}$ & $2.0 \times 10^{2}$ & $1.58 \times 10^{2} \pm 0.10 \times 10^{2 \mathrm{a}}$ \\
Meat & & & & & \\
Sausage & 6 & 20.0 & $0.4 \times 10^{2}$ & $1.4 \times 10^{2}$ & $0.95 \times 10^{2} \pm 0.16 \times 10^{2 \mathrm{~b}}$ \\
\hline
\end{tabular}

* Percentage in relation to total number of samples in each row.

Table (5): Incidence of Staphylococcus species strains isolated from examined samples

\begin{tabular}{ccccccccc}
\hline \multirow{2}{*}{ Samples } & \multicolumn{4}{c}{ S. aureus } & \multicolumn{4}{c}{ Staphylococcus species } \\
& NO. epidermidis & \multicolumn{2}{c}{ S. chromogenes } & \multicolumn{2}{c}{ Total } \\
& 3 & $\%$ & NO. & $\%$ & NO. & $\%$ & NO. & $\%$ \\
\hline Beef Burger & 10.0 & 11 & 36.7 & 0 & 0.0 & 14 & 46.7 \\
Beef Kofta & 7 & 23.3 & 10 & 33.3 & 2 & 6.7 & 19 & 63.3 \\
Minced Meat & 8 & 26.7 & 11 & 36.7 & 1 & 3.3 & 20 & 66.7 \\
Sausage & 6 & 20.0 & 11 & 36.7 & 0 & 0.0 & 17 & 56.7 \\
Total (120) & 24 & 20.0 & 43 & 35.8 & 3 & 2.5 & 70 & 58.3 \\
\hline
\end{tabular}

Percentage in relation to total number of samples in each row (30 for each sample $\& 120$ for total). 
Table (6): Coagulase activities of isolated Staphylococcus species from examined samples of meat products ( $\mathrm{n}=$ for each sample)

\begin{tabular}{ccccc}
\hline $\begin{array}{c}\text { Staphylococcus } \\
\text { strains }\end{array}$ & \multicolumn{2}{c}{$\begin{array}{c}\text { coagulase } \\
\text { positive } S . \\
\text { aureus }\end{array}$} & $\begin{array}{c}\text { coagulase } \\
\text { strains }\end{array}$ & \multicolumn{2}{c}{ strains } \\
\hline Samples & NO. & $\%^{*}$ & NO. & $\%^{*}$ \\
Beef Burger & 3 & 10.0 & 11 & 36.7 \\
Beef Kofta & 7 & 23.3 & 12 & 40.0 \\
Minced Meat & 8 & 26.7 & 12 & 40.0 \\
Sausage & 6 & 20.0 & 11 & 36.7 \\
Total & 24 & 20.0 & 46 & 38.3
\end{tabular}

*Percentage in relation to total number of each sample in each row (30 for each sample $\& 120$ for total).

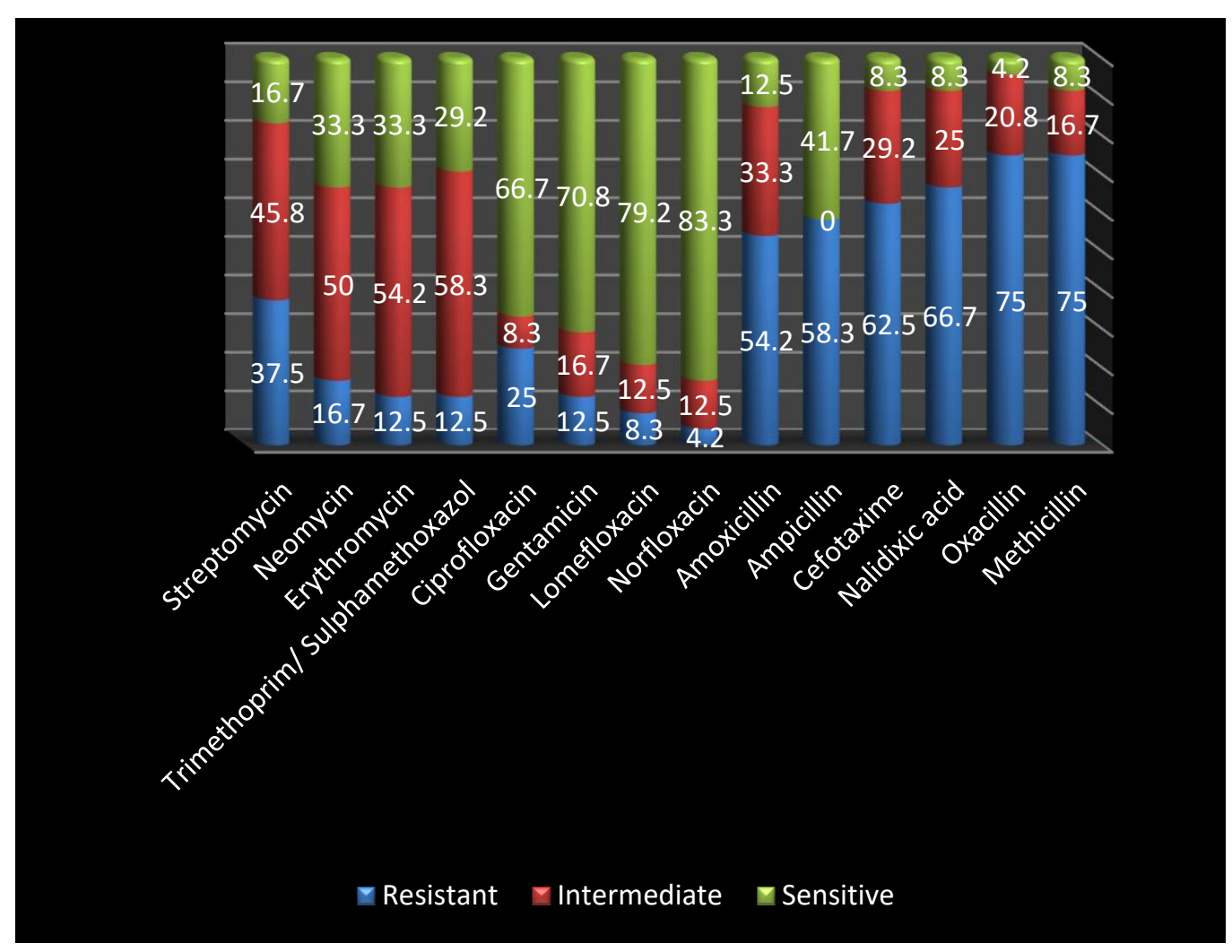

Fig. (1): In-Vitro anti-microbial Sensitivity test for isolated S. aureus strains 


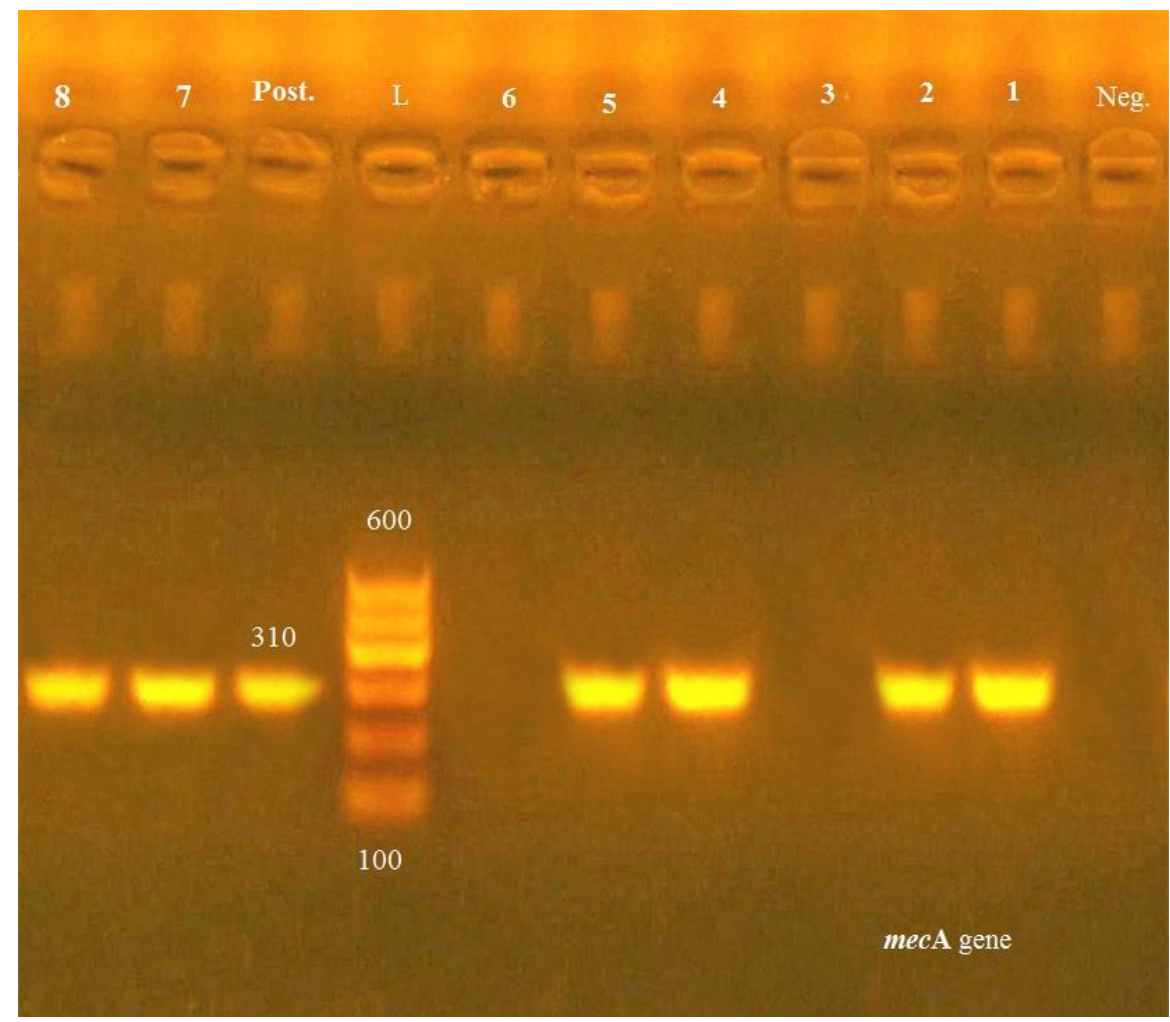

Fig. (2): Methicillin resistant (mecA) gene

Lane L: 100-600 bp DNA Ladder. $\quad$ Neg.: Negative control (Listeria reference: NCINB50007) Pos.: Positive control (S. aureus reference: ATCC25923 at $310 \mathrm{bp}$ ).

Lane 1; 2; 4; 5; 7\&8: S. aureus (Positive). Lane 3\&6: S. aureus (Negative).

\section{z. DISCUSSION}

Meat products are common vehicle of food borne illness, Staphylococci mainly S. aureus and MRSA are the most important causes of outbreaks and the presence of these organisms has relevant public health implications (Bunnoeng et al., 2013). Therefore, this study was conducted to throw light over the prevalence of Staphylococci with special reference to $S$. aureus and MRSA in common meat products (minced meat; beef kofta; sausage and beef burger) sold in supermarkets in Kaliobia Governorate beside the phenotypic characterization of the isolated $S$. aureus strains and genotypic detection of $m e c \mathrm{~A}$ virulence gene in them.

\subsection{Total aerobic bacterial count (APC)}

The total aerobic bacterial count is important for evaluation of sanitary condition of beef and meat products and can be used as indicator of bad hygiene during food processing and bad storage conditions that can lead to toxins production and pathogens proliferation (Zweifel et al., 2005). As all examined samples of minced meat; beef kofta and sausage were lower than $10^{6}$ and all beef burger samples were less than $10^{5}$, so all of them were accepted following E.S. (2005). Moreover, the statistical results revealed that, minced meat and beef kofta samples showed a significant $(\mathrm{P} \leq 0.05)$ increase of APC when compared with sausage and beef burger samples. Meanwhile, there were no significant difference $(\mathrm{P}>0.05)$ of APC between minced meat and beef kofta samples. Moreover, sausage samples showed a significant $(\mathrm{P} \leq 0.05)$ increase of APC when compared with beef burger samples. Nearly similar counts were recorded by Hamed et al. 
(2015). Meanwhile, the results disagreed with those of Abd El-Aziz- wafaa (2015) who recorded higher counts. Also, disagreed with Mousa et al. (2014) who obtained lower counts.

\subsection{Total Staphylococcus count:}

Staphylococci were a part of normal flora of animal and man, because their ubiquitous occurrence in nature, they were found in various raw foods, at the mean time foodborne illness from Staphylococcus enterotoxins remains a major problem worldwide (Normanno et al., 2007). The obtained results in (Table,2) of total Staphylococcus count came in agreement with those reported by Gibriel et al. (2007). Meanwhile, the results disagree with Abd ElAziz- wafaa (2015) who recorded higher counts.

Moreover, the statistical results revealed that, minced meat and beef kofta samples showed a significant $(\mathrm{P} \leq 0.05)$ increase of Staphylococci counts when compared with other ones. Moreover, there were no significant difference $(\mathrm{P}>0.05)$ of Staphylococci counts between minced meat and beef kofta samples and between sausage and beef burger samples. This may be due to the combination of the low quality of beef carcass used; spreading of bacteria in meat by grinding; poor manufacturing processes; inadequate cleaning and disinfection of both equipment; inadequate refrigerating and surfaces or poor personal hygiene and use of untrained personnel. These results came in accordance with that obtained by Maarouf and Nassif-Marionette (2008) and Abd ElSalam-Azza et al. (2014).

\subsection{Total Staphylococcus aureus count}

The presence of $S$. aureus in foods commonly indicates direct contamination from worker's hands with abrasion and wounds or inadequately cleaned equipment resulting in $S$. aureus intoxication.
Accordingly, the total $S$. aureus count can be taken as an index of sanitary conditions under which the meat and its products are manufactured and handled (potter, 2001). The statistical results revealed that, minced meat and beef kofta samples showed a significant $(\mathrm{P} \leq 0.05)$ increase of $S$. aureus counts when compared with other ones. Moreover, there were no significant difference $(\mathrm{P}>0.05)$ of $S$. aureus counts between minced meat and beef kofta samples and between sausage and beef burger samples. In addition, all samples were accepted (Table. 3), as the permissible limit for Total Staphylococcus aureus count must be not exceed $10^{2}$ according to E.S. (2005).

Nearly similar counts were recorded by Gibriel et al. (2007). Meanwhile, the results disagreed with those of El- Daly et al. (2014) who reported higher $S$. aureus counts in examined samples.

\subsection{Isolation and identification of Staphylococci species}

The results were nearly similar to ElDaly et al. (2014) and El-Rais-Eman (2018). Meanwhile, these results disagreed with those of Jackson et al. (2013) and Contreras et al. (2015) who isolated $S$. aureus from meat products with high incidence. Also, disagreed with those recorded by Kalantari et al. (2012) who failed to isolate $S$. aureus from beef burger and beef sausage samples.

Moreover, The results of Coagulase activities of isolated Staphylococcus species strains came in accordance with those obtained by Maarouf and Nassif-Marionette (2008); Hamed et al. (2015) and El-Rais-Eman(2018). The presence of $S$. aureus in meat and its products indicates poor hygiene of meat handlers as well as lack of sterilization of utensils and they grow without pronounced change in odour or taste in the products and producing heat stable enterotoxins which lead to food poisoning with severe diarrhoea and 
gastroenteritis among consumers (Plaatjies et al., 2004).

The widespread use of antibiotics has undoubtedly accelerated the virulence of $S$. aureus, by acquiring multiple resistance genes, has become able to survive almost all antibiotic families (Stefani and Goglio, 2010). The in-vitro sensitivity tests for the isolated $S$. aureus (Fig. ,1) showed that, the isolated $S$. aureus were highly resistant for methicillin and oxacillin $(75.0 \%$ for each) followed by nalidixic acid $(66.7 \%)$; cefotaxime $(62.5 \%)$; ampicillin (58.3\%) and amoxicillin (54.2\%). Meanwhile, they were highly sensitive to norfloxacin (83.3\%) followed by lomefloxacin (79.2\%); gentamycin $(70.8 \%)$ and ciprofloxacin $(66.7 \%)$. Moreover, they were intermediate sensitive to Trimethoprim / Sulphamethoxazol $\quad(58.3 \%)$; erythromycin (54.2\%); neomycin (50.0\%) and streptomycin (45.8\%). These results agreed with those reported by El-Rais-Eman(2018). The resistance to methicillin occurred mainly due to the presence of mecA gene on $S$. aureus chromosome that responsible for the production of Penicillin binding protein PBP2a. (Ito et al., 2004).In addition, the results proved that multiple antibiotic resistances are widely spread among isolated strains of $S$. aureus and decided the fact of Shalini and Rameshwar (2005) that the food chain can be considered as the main route of transmission of antibiotic resistant bacteria between the animal and human populations. Moreover, a strong correlation between methicillin resistance and co-resistance to non- $\beta$ - lactam antibiotics has been reported (Otalu et al., 2011).

Regarding to the PCR results for detection of methicillin-resistant $S$. aureus (MRSA) strains, (Fig., 2) showed that, the mecA gene was amplified in 6 out of 8 studied $S$. aureus strains $(75.0 \%)$ giving product of $310 \mathrm{bp}$. Similar detection of mecA gene in S. aureus strains (MRSA) were recorded by Bunnoeng et al. (2013); Contreras et al. (2015); Khosravi et al. (2017) and El-RaisEman(2018). Meanwhile, Abdalrahman et al. (2015) failed to detect mecA gene in $S$. aureus strains and said that, this might be due to over production of $\beta$-lactamase enzymes or the presence of a variant mecA gene that does not amplify with the available PCR primers.

Finally, the recorded results demonstrates that, $S$. aureus and MRSA strains are commonly found in common meat products sold in markets in Kaliobia Governorate. Presence of MRSA in meat products may pose a potential threat to human health.

\section{REFERENCES}

Abd El-Aziz-Wafaa, M. (2015): Bacterial hazards associated with consumption of street vended meat products in Kaliobia governorate. M.V.Sc. Thesis (Meat Hygiene), Fac. Vet. Med., Benha Univ. Egypt.

Abd El-Salam-Azza, S. 2014. Molecular detection of antimicrobial resistance for some food borne pathogens. Ph. D. Thesis (Bacteriology, Mycology and Immunology) Fac. Vet. Med. Zagazig Univ.

Abdalrahman,L.S; Stanley,A.; Wells,H. and Fakhr,M.K. (2015): Isolation, virulence, and antimicrobial resistance of methicillin-resistant Staphylococcus aureus (MRSA) and methicillin sensitive Staphylococcus aureus (MSSA) Strains from Oklahoma retail poultry meats. Int. J. Environ. Res. Public Health, 12: 6148-6161. 
APHA “American Public Health Association" (2001): "Compendium of Methods for the Microbiological examination of Foods". $4^{\text {th }}$ Ed. F.P. Downes and K. Ito(editors), APHA. Washington D.C., USA.

Bunnoeng, N.; Themphachana, M.; Pewleang, T.; Kongpheng, S.; Singkhamanan, K.; Saengsuwan, P. and Sukhumungoon, P. (2013): High prevalence and molecular characterization of methicillinresistant Staphylococcus aureus isolated from retailed meats, south Thailand. International Food Research J., 21(2): 569-576.

Contreras, C.P.; Nunes Da Silva, L.N.; Ferreira, D.C.; Ferreira, J.D. andAlmeida, R.C.(2015):Prevalence of Methicillin-Resistant Staphylococcus aureus in Raw Hamburgers and Ready-to-Eat Sandwiches Commercialized in Supermarkets and Fast Food Outlets in Brazil.J. Food and Nutrition Sciences, 6:1324-1331.

E.S. (2005a): "Egyptian Organization for Standardization and Quality Control for Oriental Beef Sausage" EOS $1114 / 2005$.

El-daly, E.A.; Nermeen, F. El Shopary and Rasha, M. El Bayomi (2014): Detection of enterotoxigenic S. aureus genes prevalent in some meat products using Multiplex PCR. The 1st Int. Conf. On The Impact Of Environmental Hazards On Food Safety, Zagazig University J. August 20th 2014. p 162-168.

El-Rais, Eman, M.A. (2018): Bacteriological and Molecular Studies on Antibiotic Resistant Bacteria in Some Meat Products. M.V.SC. Thesis
(Bacteriology, Immunology and Mycology), Fac. Vet. Med. Benha Univ.

FDA Food and Drug Administration. 2001. Center for Food safety and applied nutrition. (www.FDA.org.).

Gibriel, A. Y.; Ebeid, H. M.; Khalil, H. I. and Abdel-Fattah, A. A. (2007): Application of Monascus purpureus pigments produced using some food industry wastes in beef sausage manufacture. Egyptian Journal of Food Science. 35: 27-45.

Gundogan, N. and Devren, A. (2010): Protease and lipase activity of Staphylococcus aureus obtained from meat, chicken and meatball samples. Gu J Sc., 23 (3): 381-384.

Hamed, E. A.; Ahmed, A. S. and Abd ElAaty, M. F. 2015. Bacteriological hazard associated with meat and meat products. Egypt. J. Agric. Res., 93, 4 (B): 385-393.

Hanson, B. M.; Dressler, A. E.; Harper, A. L.; Scheibel, R. P.; Wardyn, S. E. and Roberts, L. K. (2011): Prevalence of Staphylococcus aureus and methicillin-resistant Staphylococcus aureus (MRSA) on retail meat in Iowa. Journal of Infection and Public Health, 4: 169-174.

Ito, T.; Ma, X.X.; Takeuchi, F.; Okuma, K.; Yuzawa, H. and Hiramatsu, K. (2004): Novel type V staphylococcal cassette chromosome mec driven by a novel cassette chromosome recombinase, ccrC. Antimicrob Agents Chemother ,48 : 2637-2651.

Jackson, C. R.; Davis, J. A. and Barrett, J. B. (2013): "Prevalence and characterization of MethicillinResistant Staphylococcus aureus 
isolates from retail meat and humans in Georgia". J. Clinic. Microbiol., 51(4):1 199-1207.

Kalantari, S.; Sepehri, G.; Bahrampour, A. and Sepehri, E. (2012): Determination of bacterial contamination isolated from sandwiches in Kerman City and their resistance to commonly used antimicrobials, Arch. Appl. Sci. Reds., 4(2): 1100-1105.

Khosravi, A.D.;Jenabi, A. and Montazeri, E.A.(2017): Distribution of genes encoding resistance to aminoglycoside modifying enzymes in methicillin-resistant

Staphylococcus aureus (MRSA) strains. Kaohsiung J. Med. Sci., 33(12):587-593.

Konemann, E.; Allen, S.; Janda, W.; Schreckenberger, C. and Winn, W. (1997): Color Atlas and Textbook of Diagnostic Microbiology. Fifth Edition. Lippincott, Philadelphia, New York.

Llewelyn, M. and Cohen, J. 2002. Super antigens: Microbial agents that corrupt immunity. Lancet. Infect. Dis., 2: 156162.

Maarouf, A.A. and Nassif-Marionette. 2008. Bacteriological studies on frozen cow meat and some meat products at Benha city. Journal of the Egyptian Vet. Med. Assoc., 68 (1):129-141.

McClure, J.A.; Conly, J.M.; Lau, V.; Elsayed, S.; Louie, T.;Hutchins, W. and Zhang, K. (2006): Novel multiplex PCR assay for detection of the Staphylococcal virulence marker Panton-Valentine leukocidin genes and simultaneous discrimination of methicillin-susceptible from resistant Staphylococci. J. Clin.
Microbiol., 44: 1141-1144.

Mousa, M. M.; Ahmed, A. A. and ElShamy, S. Y. (2014): Microbiological criteria of some meat products. Alexandria .J. Vet. Sci., 42 (1): 83-8.

Normanno, G.; La Salandra, G.; Dambrosio, A.; Quaglia, N.C. ; Corrente , M.; Parisi, A.; Santagada, G.; Firin, U. A.; Crisetti, E. and Celano, G. V. 2007. Occurrence, characterization and antimicrobial resistance of enterotoxigenic Staphylococcus aureus isolated from meat and dairy products. International J. Food Microbiology, 115: 290-296.

Otalu, O.J.; Junaidu, K.;Chukwudi, O.E. and Jarlath, U.V.(2011): Multidrug Resistant Coagulase Positive Staphylococcus aureus from Live and Slaughtered Chickens in Zaria Nigeria. Int. J. Poult. Sci.,10 (11): 871-875.

Park, C.E.; Akhtar, M. and Rayman, M. K. 1994. Evaluation of commercial enzyme immunoassay kit (RIDASCREEN) for detection of staphylococcal enterotoxins A, B, C, $\mathrm{D}$, and $\mathrm{E}$ in foods. Appl. Environ. Microbiol., 60: 677.

Plaatjies, Z.; Lues, J. and Buys, E. 2004. Staphylococcal growth in fresh vacuum-packed red meat at various storage conditions. $8^{\text {th }}$ World Congress on Environmental Health. Durban, South Africa.

Potter, N. N. (2001): "Food Science". 3rd Ed. The AVI Publishing Co., INC. New York, USA.

Prescott, M.; Harley, P. and Klein, D. A. 2005 Microbiology. $6^{\text {th }}$ Ed. McGraw Hill. New York U.S.A.: p. 910. 
Quinn, P. J., Markey, B. K., Carter, M. E., Donnelly, W. J. C., Leonard, F. C. and Maguire, D. 2002 . Veterinary microbiology and microbial disease. Iowa State Univ. Press, Blackwell Science Ltd, 26-36: 84-96.

Sambrook, J.; Fritsch, E.F. and Montias, T. (1989): Molecular Biology. In: Molecular cloning. Laboratory manual, Second Edition. Cold Spring Harbor Laboratory press, USA.

Sasidharan, S.;Prema, B. and Yoga Ltha, L. (2011): Antimicrobial drug resistance of Staphylococcus aureus in dairy products. Asian Pcific Journal of Tropical Biomiedicine: 130-132.

Shalini, M. and Rameshwar, S. (2005): "Antibiotic resistance in food lactic acid bacteria - a review". International Journal of Food Microbiology, 105:281-295.

Shijia ， W. ;Nuo,D.;Huajie,G.; liling H.;Huax.,Wenhui,G. AND Zhouping W.(2016): A review of the methods for detection of Staphylococcus aureus Enterotoxins . Toxins J.,8,176; doi : $10.3390 / \quad$ toxins 8070176 .

Snedecor, G.W. and Cochran, W.G. 1969. Statistical Methods, 6th Ed. Iowa State University Press, Asmes, USA.

SPSS for windows, Version: $11 \quad$ (19 September 2001). Copyright SPSS Inc. 1989 - 2001. All rights reserved.

Stefani, S. and Goglio, A.( 2010): Methicillinresistant Staphylococcus aureus: Related infections and antibiotic resistance. Int. J. Infect. Dis., 14: 1922.

Stefani, S. and Goglio, A.( 2010): Methicillinresistant Staphylococcus aureus: Related infections and antibiotic resistance. Int. J. Infect. Dis., 14: 1922.

Yang, H.; Xiaoyan, M.A.; Zhang, X.; Wang, Y. and Zhang, W. (2011): Development and evaluation of a loop mediated isothermal amplification assay for the rapid detection of S. aureus in food. Eur. Food Res. Technol., 232: 769-776.

Zafar, A.; Ahmed, E.; Wajiha, H. and Khan, A. 2016. Microbiological Evaluation of Raw Meat Products Available in Local Markets of Karachi, Pakistan. Pakistan Academy of Sciences B. Life and Environmental Sciences 53 (2): 103-109.

Zweifel, C., Baftzer, D.,and Stephan, R., (2005): Microbiological contamination of cattle and pig ' carcasses at five abattoirs determined by swab sampling in accordance with Eu. Decision 2001/471/EC .J. Meat Sci., 69:559_566. 